\title{
Effectiveness of bacterial infection-related cytokine profile (BIRCP) determination for monitoring pathogen infections in children with hemopathy in the bone marrow inhibition phase
}

\author{
X.D. Chen ${ }^{1}$, B. Chen ${ }^{2}$, Y.M. Tang ${ }^{1}$, H. Song ${ }^{1}$, S.W. Shi ${ }^{1}$, S.L. Yang ${ }^{1}$, \\ W.Q. Xu' ${ }^{1}$, B.H. Pan ${ }^{1}$, F.Y. Zhao ${ }^{1}$, N. Zhao ${ }^{1}$, L.Y. Zhang ${ }^{1}$ and J.Q. Mao ${ }^{1}$ \\ ${ }^{1}$ Department of Hematology and Oncology, \\ Children's Hospital Affiliated with Zhejiang University School of Medicine, \\ Hangzhou, Zhejiang Province, China \\ ${ }^{2}$ Department of Rehabilitation, \\ Hangzhou Hospital of the Zhejiang Armed Police Corps, Hangzhou, \\ Zhejiang Province, China
}

Corresponding author: X.D. Chen

E-mail: xddoccn@yeah.net

Genet. Mol. Res. 13 (4): 10622-10631 (2014)

Received July 25, 2013

Accepted November 29, 2013

Published December 18, 2014

DOI http://dx.doi.org/10.4238/2014.December.18.4

\begin{abstract}
Serum cytokine profiles were analyzed before and after infection in children with hemopathy in the bone marrow inhibition phase to explore the utility of cytokine variations for detecting infections. Serum Th1/Th2 cytokine levels, including tumor necrosis factor, interleukin (IL)-2, IL-4, IL-6, IL-10, and interferon, were quantitatively determined by cytometric bead array technology in 480 cases (230 children) of children with hemopathy in the bone marrow inhibition phase with signs of infection, such as fever, and without, to establish baseline and affected levels for comparison with healthy control children. We used the cytokine profile of infected, blood culture-positive children to establish a bacterial infection-related cytokine profile (BIRCP) for
\end{abstract}


predicting infections by pathogens in blood culture-negative children. Overall, $82.9 \%$ of children with Gram-negative bacterial infections were accompanied by marked increases of IL- 6 and IL-10 levels [ $>10$ times (means $\pm \mathrm{SD}$ )], whereas only a mild increase of IL-6 levels occurred in Gram-positive bacteria-infected children [ $>2$ times (means $\pm \mathrm{SD}$ )] and only a mild increase of IFN- $\gamma$ levels occurred in fungal culturepositive children $[>2$ times (means $\pm \mathrm{SD}$ )]. Gram-positive bacterial and fungal infections did not cause a marked increase in IL-6 or IL10 levels. The effective rate $(86.05 \%, \mathrm{~N}=43)$ of infectious cases predicted by BIRCP was significantly higher than that obtained using traditional methods for selecting antibiotics based on clinical indications $(65.45 \%, \mathrm{~N}=55, \mathrm{P}<0.05)$. In summary, BIRCP can be used to predict the infections by pathogens in children with hemopathy and to select appropriate antibiotics.

Key words: Children; Hemopathy; Phase of bone marrow inhibition; Infection; Cytokine profile

\section{INTRODUCTION}

When children with hemopathy are in the bone marrow inhibition phase, owing to chemotherapy and other factors, their white blood cell count is extremely low and their absolute neutrophil count is less than $1000 / \mu \mathrm{L}$, making them extremely susceptible to nosocomial infection (Simon et al., 2005; Mendes et al., 2007). Until recently, infection has been the leading cause of death in hemopathy patients (Mendes et al., 2007).

Infection can be diagnosed based on fever, rash, toxic symptoms, localized infection symptoms, and clinical signs, as well as from the results of general laboratory examinations [such as routine blood tests, C-reactive protein (CRP) levels, or chest X-rays] or specific pathogen examination (such as blood cultures, immune antigen detection, and antibody levels). In the phase of bone marrow suppression, the number of white blood cells, especially neutrophils, are extremely low in children with hemopathy, but often no other obvious phenomenon is present. In addition, CRP levels are generally elevated during infectious and noninfectious fever (von Lilienfeld-Toal et al., 2004), but are also affected by colony stimulating factor drugs (Park et al., 2008; Ikonomidis et al., 2008). Therefore, routine blood tests and CRP measurements have poor sensitivity and specificity for these cases. A further complication is that the rates of pathogen isolation and culture are extremely low in these cases. Children are often given empirical treatments that include broad-spectrum antibiotics in the absence of an etiological basis (Laws et al., 2005; Lehrnbecher and Laws, 2005), which depends on the clinical experience and diagnostic expertise of individual clinicians. This setting could easily lead to the abuse of antibiotics, causing the emergence of drug-resistant strains and increasing the physical and economic burdens on these patients (Simon et al., 2005).

Cytokines are a class of minor polypeptides secreted by a variety of cells that can regulate cell growth and differentiation, modulate immune function, and participate in inflammation and wound healing. Bacteria, viruses, and other microbes can stimulate the production of cytokines, which can induce other cells and cytokines to be involved in the inflammatory response through a chain reaction. Serum concentrations of many cytokines, including interleukin (IL)-2, IL-4, IL-6, 
IL-10, tumor necrosis factor (TNF)- $\alpha$, and interferon (IFN)- $\gamma$, usually change soon after infection and before CRP levels increase (Roitt et al., 2001). Cytometric bead array (CBA) technology is currently used in our hospital to measure cytokine concentrations, which has the advantages of requiring less serum, offering many cytokines to measure, allowing faster processing, having a lower error rate and cost, demanding less labor, and yielding a larger detection range compared to the traditional enzyme-linked immunosorbent assay (ELISA) method (Tárnok et al., 2003). Correlation coefficients for these methods are $>90 \%$ (Tárnok et al., 2003; Martins et al., 2003). These advantages make the rapid determination of cytokines by CBA feasible.

To date, there have been many studies on the detection of single cytokines to sensitively detect the early stages of infection (Diepold et al., 2008), as well as to assist in generating infection prognoses (Martins et al., 2003). There have also been some studies conducted on single cytokines to predict pathogen infections, but few have used multi-cytokine profiling to monitor for infection. In this study, the changes in cytokine profiles from before and after infection in children with hemopathy in the bone marrow inhibition phase were analyzed to explore the utility of using this method to detect characteristics of infection and to provide a basis for the rational use of antibiotics based on clinical CBA profiling.

\section{MATERIAL AND METHODS}

\section{Subjects}

Our patient cohort included 230 children with fever or other symptoms of infection who were in the bone marrow inhibition phase (neutrophil absolute count $<1000 / \mu \mathrm{L}$ ) from January 2005 to July 2008 in the Hematology Department of our hospital. Our cohort included 153 males and 77 females, ranging from 13 months to 14 years old (median age, 7.2 years old). A baseline was established based on the cytokine levels in non-infected children. A total of 480 cases with obvious nosocomial infection symptoms, such as fever and cough, in the bone marrow inhibition phase during hemopathy treatment were classified as the case group, and 250 children who underwent a physical examination served as the healthy control group. This study was conducted in accordance with the Declaration of Helsinki and with the approval of the Ethics Committee of the Children's Hospital Affiliated with Zhejiang University School of Medicine. Written informed consent was obtained from all participants.

\section{Normal cytokine measurements}

We obtained serum from 230 children with hemopathy who had a non-infected status from January 2005 to July 2008 in the Hematology Department of our hospital, and then measured the serum cytokines levels of TNF- $\alpha$, IL-2, IL-4, IL-6, IL-10, and IFN- $\gamma$. A baseline range of serum cytokine levels in children with hemopathy was established using these data. Serum from 250 healthy children who underwent a physical examination served as the healthy control group, allowing us to determine whether there was any change in cytokine levels between non-infected children with hemopathy and healthy children.

\section{Serum preparation}

There were 480 instances of fever or other infection symptoms in the 230 children 
who were in the bone marrow inhibition phase during treatment. We took $1 \mathrm{~mL}$ peripheral blood samples within $24 \mathrm{~h}$ after infection and again $24 \mathrm{~h}$ later, and naturally coagulated the blood without anticoagulant. Serum cytokine levels were determined, as well as the CRP levels and blood cultures.

\section{Serum cytokine measurements}

We transferred $1 \mathrm{~mL}$ venous blood into test tubes for each sample and centrifuged tubes after coagulation at $1000 \mathrm{~g}$ for $20 \mathrm{~min}$ at $20^{\circ} \mathrm{C}$. The supernatant was stored at $2-8^{\circ} \mathrm{C}$ within $12 \mathrm{~h}$. The CBA Human Th1/Th2 Cytokine Kit II (BD Biosciences; San Jose, CA, USA) was used to determine serum TNF- $\alpha$, IL-2, IL-4, IL-6, IL-10, and IFN- $\gamma$ levels following the manufacturer protocol. In brief, the CBA technique was based on the fluorescence intensity of six different microspheres, which were linked to specific capture antibodies for TNF- $\alpha$, IL-2, IL-4, IL-6, IL10 , or IFN- $\gamma$. The fluorescent dye with the longest fluorescence emission wavelength $(\sim 650 \mathrm{~nm}$ or "FL-3") could be determined using flow cytometry (FCM). The cytokine capture beads were mixed with the detection antibody that was linked to phycoerythrin (PE) and then incubated together with either the recombinant standards or test samples to form a sandwich-type complex. The sample data were acquired using a FACSCalibur flow cytometer (Becton Dickinson; San Jose, CA, USA) and the results were analyzed using the BD CBA software (BD Biosciences) in graphical or tabular form. Six standard curves (range, $0-5000 \mathrm{pg} / \mathrm{mL}$ ) were generated, as well as the measurements of the six cytokines in the test samples. The minimum and maximum limit of detection for the six cytokines was 1.0 and $5000 \mathrm{pg} / \mathrm{mL}$, respectively.

\section{Definitions and analytical methods used for observation indexes}

The baseline ranges of IL-2, IL-4, IL-6, IL-10, TNF- $\alpha$, and IFN- $\gamma$ serum cytokine levels (reported as mean $\pm \mathrm{SD}$ ) were determined using data from the routine measurement of cytokines in 230 cases without symptoms of infection. We tested 480 cases of infection to determine the levels of cytokines within $24 \mathrm{~h}$ after infection. When the value measured increased $>2$ times $( \pm \mathrm{SD})$ and $<10$ times $( \pm \mathrm{SD})$, it was classified as a mild increase, and when it increased $>10$ times $( \pm \mathrm{SD})$, it was classified as a high increase. The cytokine levels were again measured after infection $24 \mathrm{~h}$ later, and levels $<2$ times $( \pm \mathrm{SD})$ were considered to have either normalized by 2 times ( $\pm \mathrm{SD}$ ) or not. CRP levels $>8 \mathrm{mg} / \mathrm{L}$ were considered to have increased. Reduction in fever and improved clinical symptoms after antibiotic treatment for $72 \mathrm{~h}$ were considered to indicate effective treatments.

Data from 480 cases with infection were analyzed to establish three analysis groups that included: 1) CRP levels, blood culture, and serum cytokine levels within $24 \mathrm{~h}$, at $48 \mathrm{~h}$ after infection, and at $24 \mathrm{~h}$ after infection control were compared, as well as the sensitivity of the three infection indexes; 2) among 56 confirmed culture-positive children, we analyzed the changes in cytokine levels when Gram-positive bacterial, Gram-negative bacterial, or fungal infection occurred to establish the Gram-positive and Gram-negative bacterial infection-related cytokine profiles (Gram-positive or Gram-negative BIRCP); 3) we diagnosed 43 blood culture-negative children as bacteria-infected using Gram-positive and Gram-negative BIRCP, and we administered appropriate antibiotics accordingly. There were an additional 55 cases of antibiotic treatment chosen based on clinical findings instead of BIRCP. The efficiency rates were compared between the two treatment groups, which were also compared with the multiple-coverage treatment groups. 


\section{Statistical analyses}

Data are reported as (means $\pm \mathrm{SD}$ ) and the chi-squared test was used to compare intra- and inter-group differences. Instances where $\mathrm{P}<0.05$ were considered to be statistically significant differences. The reference value was determined by two-sided confidence intervals with $\alpha=0.05$ as the level of a statistically significant difference.

\section{RESULTS}

\section{Baseline cytokine levels}

We routinely measured cytokine levels in 230 cases of children with hemopathy without symptoms of infection to establish the initial serum cytokine levels before chemotherapy, with baseline ranges of: IL-2, $5.94 \pm 1.12$; IL- 4, $2.16 \pm 1.48$; IL-6, $12.16 \pm 3.86$; IL-10, 3.85 \pm 1.27 ; TNF- $\alpha, 4.78 \pm 1.20$; and IFN- $\gamma, 15.07 \pm 4.02 \mathrm{pg} / \mathrm{mL}$.

The serum from 250 cases of healthy children without infection who underwent physical examination were classified as healthy controls, with the following baseline levels of serum cytokines: IL-2, $5.76 \pm 1.04$; IL-4, $2.37 \pm 1.61$; IL-6, $11.48 \pm 3.96$; IL-10, $4.03 \pm 1.42$; TNF- $\alpha, 4.96 \pm 1.48$; and IFN- $\gamma, 14.48 \pm 5.11 \mathrm{pg} / \mathrm{mL}$.

Where $\mathrm{N}>50$ for these two data sets, differences in cytokine levels between groups were measured using the U-test with $\alpha=0.05$ : IL-2, $\mathrm{U}=1.826, \mathrm{P}>0.05$; IL-4, $\mathrm{U}=1.489$, P $>0.1$; IL-6, U = 1.904, P > 0.05; IL-10, U = 1.466, P > 0.1; TNF- $\alpha, \mathrm{U}=1.469, \mathrm{P}>0.1$; and IFN- $\gamma \mathrm{U}=1.412, \mathrm{P}>0.1$. Our data analysis showed that there was no statistical significance at $\alpha=0.05$, indicating that there was no statistically significant difference in the baseline levels of cytokines between uninfected children with hemopathy before chemotherapy and healthy children who underwent physical examination.

\section{Cytokine measurements}

The median (and range) of the cytokine level measurements were as follows: IL-2, 6.02 (1.12-76.23); IL-4, 1.67 (<1.0-50.58); IL-6, 3787.7 (12.38-5000+); IL-10, 394.2 (3.24-5000+); TNF- $\alpha, 6.93$ (4.37-165.34); and IFN- $\gamma, 28.64$ (6.38-142.35) pg/mL (Table 1, Figure 1).

For IL-2 (baseline level, $5.94 \pm 1.04 \mathrm{pg} / \mathrm{mL}$ ), there were 20 cases $(4.17 \%$ ) over the baseline level, wherein, 2 cases $(0.42 \%)$ were $>($ means $\pm \mathrm{SD}), 14$ cases $(2.92 \%)$ were $>2$ times (means $\pm \mathrm{SD}$ ), and 4 cases $(0.83 \%)$ were $>10$ times (means $\pm \mathrm{SD}$ ).

For IL-4 (baseline level, $2.16 \pm 1.48 \mathrm{pg} / \mathrm{mL}$ ), there were 47 cases $(9.79 \%)$ over the baseline level, wherein, 7 cases $(1.46 \%)$ were $>($ means \pm SD), 34 cases $(4.58 \%)>2$ times (means $\pm \mathrm{SD}$ ), and 6 cases $(1.25 \%$ ) were $>10$ times (means $\pm \mathrm{SD}$ ).

For IL-6 (baseline level, $12.16 \pm 3.86 \mathrm{pg} / \mathrm{mL}$ ), there were 465 cases $(96.87 \%)$ over the baseline level, wherein, 18 cases $(3.75 \%)$ were $>($ means \pm SD), 22 cases $(4.58 \%)$ were $>2$ times (means $\pm \mathrm{SD}$ ), and 425 cases $(88.54 \%$ ) were $>10$ times (means $\pm \mathrm{SD}$ ).

For IL-10 (baseline level, $3.85 \pm 1.27 \mathrm{pg} / \mathrm{mL}$ ), there were 428 cases $(89.17 \%)$ over the baseline level, wherein, 25 cases $(5.21 \%)$ were $>$ (means \pm SD), 29 cases $(6.04 \%)$ were $>2$ times (means $\pm \mathrm{SD}$ ), and 374 cases $(77.92 \%)$ were $>10$ times (means $\pm \mathrm{SD}$ ).

For TNF- $\alpha$ (baseline level, $4.78 \pm 1.20 \mathrm{pg} / \mathrm{mL}$ ), there were 100 cases $(20.83 \%)$ over 
the baseline level, wherein, 8 cases $(1.67 \%)$ were $>($ means \pm SD), 61 cases $(12.71 \%)$ were $>2$ times (means $\pm \mathrm{SD}$ ), and 10 cases $(6.45 \%)$ were $>10$ times (means $\pm \mathrm{SD}$ ).

For IFN- $\gamma$ (baseline level, $15.07 \pm 4.02 \mathrm{pg} / \mathrm{mL}$ ), there were 282 cases $(58.75 \%)$ over the baseline level, wherein, 48 cases $(10.0 \%)>($ means \pm SD), 221 cases $(46.04 \%)$ were $>2$ times (means $\pm \mathrm{SD}$ ), and 13 cases $(2.71 \%)$ were $>10$ times (means $\pm \mathrm{SD}$ ).

Table 1. Positive rate of six kinds of cytokines in 480 cases within $24 \mathrm{~h}$ after infection (means \pm SD).

\begin{tabular}{|c|c|c|c|c|c|c|}
\hline & $\begin{array}{c}\text { IL-2 } \\
5.94 \pm 1.04\end{array}$ & $\begin{array}{c}\text { IL-4 } \\
2.16 \pm 1.48\end{array}$ & $\begin{array}{c}\text { IL-6 } \\
12.16 \pm 3.86\end{array}$ & $\begin{array}{c}\text { IL-10 } \\
3.85 \pm 1.27\end{array}$ & $\begin{array}{c}\text { TNF } \\
4.78 \pm 1.20\end{array}$ & $\begin{array}{c}\text { IFN- } \gamma \\
15.07 \pm 4.02\end{array}$ \\
\hline$<($ means $\pm \mathrm{SD})$ & $\begin{array}{c}460 \\
(95.83 \%)\end{array}$ & $\begin{array}{c}433 \\
(90.21 \%)\end{array}$ & $\begin{array}{c}15 \\
(3.13 \%)\end{array}$ & $\begin{array}{c}52 \\
(10.83 \%)\end{array}$ & $\begin{array}{c}380 \\
(79.17)\end{array}$ & $\begin{array}{c}198 \\
(41.25 \%)\end{array}$ \\
\hline$>($ means $\pm \mathrm{SD})$ & $\begin{array}{c}2 \\
(0.42 \%)\end{array}$ & $\begin{array}{c}7 \\
(1.46 \%)\end{array}$ & $\begin{array}{c}18 \\
(3.75 \%)\end{array}$ & $\begin{array}{c}25 \\
(5.21 \%)\end{array}$ & $\begin{array}{c}8 \\
(1.67 \%)\end{array}$ & $\begin{array}{c}48 \\
(10.0 \%)\end{array}$ \\
\hline$>2$ times $($ means $\pm \mathrm{SD})$ & $\begin{array}{c}14 \\
(2.92 \%)\end{array}$ & $\begin{array}{c}34 \\
(7.08 \%)\end{array}$ & $\begin{array}{c}22 \\
(4.58 \%)\end{array}$ & $\begin{array}{c}29 \\
(6.04 \%)\end{array}$ & $\begin{array}{c}61 \\
(12.71 \%)\end{array}$ & $\begin{array}{c}221 \\
(46.04 \%)\end{array}$ \\
\hline$>10$ times $($ means $\pm \mathrm{SD})$ & $\begin{array}{c}4 \\
(0.83 \%)\end{array}$ & $\begin{array}{c}6 \\
(1.25 \%)\end{array}$ & $\begin{array}{c}425 \\
(88.54 \%)\end{array}$ & $\begin{array}{c}374 \\
(77.92 \%)\end{array}$ & $\begin{array}{c}31 \\
(6.45 \%)\end{array}$ & $\begin{array}{c}13 \\
(2.71 \%)\end{array}$ \\
\hline Total positive rate & $4.17 \%$ & $9.79 \%$ & $96.87 \%$ & $89.17 \%$ & $20.83 \%$ & $58.75 \%$ \\
\hline
\end{tabular}

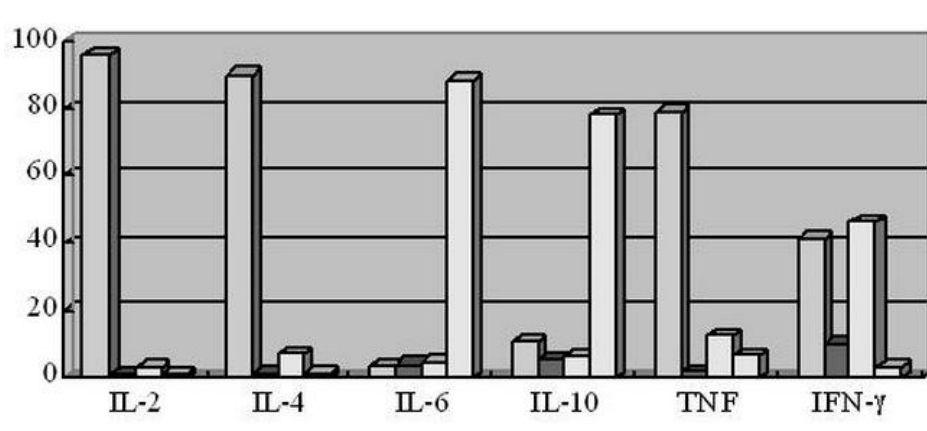

Four groups of six kinds of cytokines respectively were as follows:

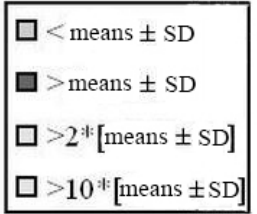

Figure 1. Positive rates of six kinds of cytokines in 480 cases within $24 \mathrm{~h}$ after infection.

\section{Variation of cytokine levels, CRP levels, and blood culture indicators}

We found that within $24 \mathrm{~h}$ after infection (before cases became blood culture-positive), $93.3 \%$ of cases showed increased cytokine levels, but only $26.7 \%$ of cases showed increased CRP levels. At $48 \mathrm{~h}$ after infection (cases were not yet blood culture-positive), $90.8 \%$ of cases showed increased CRP levels. At $24 \mathrm{~h}$ following indications of infection control, the cytokine normalization rate was $97.3 \%$, but the CRP normalization rate was only $12.7 \%$. There were a total of 56 culture-positive children who later became culture-negative. Our results showed that the sensitivity of cytokine detection in the early stage (within $24 \mathrm{~h}$ ) of infection was higher than that of CRP or blood culture, and that cytokine levels gave a better indication of whether an infection was under control than did CRP levels. In 480 cases with fever or other symptoms of infection, there were 56 cases $(11.67 \%)$ with blood culture-positive infections and 424 cases $(88.33 \%)$ of blood culture-negative suspected infections. Among the blood culturepositive cases, there were 8 cases $(1.67 \%)$ of Gram-positive bacteria, 42 cases $(8.75 \%)$ of Gram-negative bacteria, and 6 cases $(1.25 \%)$ of fungus infection. 


\section{Establishment of BIRCP parameters}

We used 56 confirmed culture-positive cases to determine Gram-negative and Grampositive BIRCP (Table 2, Figure 2) parameters. We classified the changes in cytokine levels measured in these cases within $24 \mathrm{~h}$ after infection, defining values $>2$ times (means $\pm \mathrm{SD}$ ) as mild increases and $>10$ times (means $\pm \mathrm{SD}$ ) as high increases. The cytokines listed in Table 2 were measured using $\mathrm{R} \times \mathrm{C}$ contingency table chi-squared inspection (for example, the intra-group analysis of IL-6, $\chi^{2}=37.26, \mathrm{P}<0.05$ ) to test for statistically significant differences. Our results showed that the Gram-negative bacteria group showed a statistically significant increase of IL-6 and IL-10 levels $(\mathrm{P}<0.05)$ and no statistically significant change in IL-2, IL-4, TNF- $\alpha$, or IFN- $\gamma$ levels $(\mathrm{P}>0.05)$, indicating that IL-6 and IL-10 levels significantly increased in Gram-negative bacterial infections (wherein, $5.13 \%$ of cases had a mild increase and $94.87 \%$ of cases had a high increase of IL-6, and $7.89 \%$ of cases had a mild increase and $92.11 \%$ of cases had a high increase of IL-10), with most cases showing a high increase [ $>10$ times (means $\pm \mathrm{SD}]$. Based on our data, there was only a mild increase of IL- $6>2$ times (means \pm SD) and $<10$ times (means \pm SD), but no obvious change in IL-10 or IFN- $\gamma$ levels in Gram-positive bacteria-infected children, and only a mild increase of IFN- $\gamma$ levels [ $>2$ times (means \pm SD), $<10$ times (means \pm SD)], but no obvious change in IL-6 or IL-10 levels in fungus-infected children. Therefore, the simultaneous high increase of IL- 6 and IL-10 [>10 times (means \pm SD)], as well as the lack of significant changes $[<2$ times (means \pm SD) $]$ in IL-2, IL-4, and TNF- $\alpha$ levels were defined as the Gramnegative BIRCP, while a mild increase of IL-6 levels [ $>2$ times (means \pm SD), $<10$ times (means $\pm \mathrm{SD}$ )], as well as the lack of significant changes $[<2$ times (means \pm SD)] in IL-2, IL-4, IL-10, TNF- $\alpha$ and IFN- $\gamma$ levels were defined as the Gram-positive BIRCP. Due to the small number of confirmed fungal infections, we did not establish a Fungal Infection-Related Cytokine Profile.

\begin{tabular}{|c|c|c|c|c|c|c|}
\hline & $\begin{array}{c}\text { IL-2 } \\
5.94 \pm 1.04\end{array}$ & $\begin{array}{c}\text { IL-4 } \\
2.16 \pm 1.48\end{array}$ & $\begin{array}{c}\text { IL-6 } \\
12.16 \pm 3.86\end{array}$ & $\begin{array}{c}\text { IL-10 } \\
3.85 \pm 1.27\end{array}$ & $\begin{array}{c}\text { TNF } \\
4.78 \pm 1.20\end{array}$ & $\begin{array}{c}\text { IFN- } \gamma \\
15.07 \pm 4.02\end{array}$ \\
\hline \multicolumn{7}{|c|}{ Gram-negative bacteria (42 cases) } \\
\hline$>2$ times (means $\pm \mathrm{SD})$ & 13 & 3 & 2 & 3 & 9 & 17 \\
\hline$>10$ times (means $\pm \mathrm{SD})$ & 0 & 0 & 37 & 35 & 1 & 1 \\
\hline Total & $13(3.1 \%)$ & $3(7.1 \%)$ & $39(92.8 \%)$ & $38(90.5 \%)$ & $10(23.8 \%)$ & $18(42.9 \%)$ \\
\hline \multicolumn{7}{|c|}{ Gram-positive bacteria ( 8 cases) } \\
\hline$>2$ times (means $\pm \mathrm{SD})$ & 0 & 0 & 8 & 1 & 0 & 1 \\
\hline$>10$ times (means $\pm \mathrm{SD})$ & 0 & 0 & 0 & 0 & 0 & 0 \\
\hline Total & $0(0 \%)$ & $0(0 \%)$ & $8(100 \%)$ & $1(10 \%)$ & $0(0 \%)$ & $1(10 \%)$ \\
\hline \multicolumn{7}{|l|}{ Fungi ( 6 cases) } \\
\hline$>2$ times $($ means $\pm \mathrm{SD})$ & 0 & 0 & 1 & 0 & 0 & 6 \\
\hline$>10$ times (means $\pm \mathrm{SD})$ & 0 & 0 & 0 & 0 & 0 & 0 \\
\hline Total & $0(0 \%)$ & $0(0 \%)$ & $1(16.7 \%)$ & $0(0 \%)$ & $0(0 \%)$ & $6(100 \%)$ \\
\hline
\end{tabular}

\section{General data}

Among 424 cases of infection in blood culture-negative children, 55 cases presented skin infection, catheter infection, chills, or circulatory failure, and were later found to have been infected with identifiable pathogens. These cases were given appropriate antibiotics based on their clinical signs and BIRCP (including 12 cases of Gram-positive bacteria and 43 cases of Gram-negative bacteria). We diagnosed 43 cases of infection by cytokine level changes and gave these patients antibiotics based on their Gram-negative or Gram-positive BIRCP (includ- 
ing 8 cases of Gram-positive bacteria infection who were given vancomycin treatment and 35 cases of Gram-negative bacteria infection who were given sulperazone treatment). The other 326 cases were given a multiple-coverage therapy consisting of broad-spectrum antibiotics (carbopenems + sulperazone + vancomycin) + antifungal (fluconazole) + antiviral (ganciclovir). Table 3 shows that patient clinical conditions improved after treatment with antibiotics for $72 \mathrm{~h}$. Terms " 1 " and "2" in Table 3 were measured using the R x C chi-squared test with $\chi^{2}$ $=4.356$ and $0.025<\mathrm{P}<0.05$, which indicated that the efficiency rate in the BIRCP treatment group was greater than that in the clinical experience group, based on a statistical significance at $\alpha=0.05$. Terms " 1 " and " 3 " in Table 3 were measured using the $\mathrm{R} x \mathrm{C}$ chi-squared test with $\chi^{2}=0.398,0.5<\mathrm{P}<0.75$, which was considered as no significance difference between the BIRCP group compared with the broad-spectrum coverage group $(\mathrm{P}>0.05)$ according to $\alpha=$ 0.05 . These data indicate that the effective rate $(86.05 \%)$ in children using Gram-positive and Gram-negative BIRCP to predict infectious agents and guide the use of antibiotics was significantly higher than that obtained when using clinical experience to select antibiotics $(65.45 \%$, $\mathrm{P}<0.05)$ and was almost equivalent $(89.26 \%, \mathrm{P}>0.5)$ to the use of broad-spectrum antimicrobial + antifungal + antiviral multiple-coverage therapy. The antibiotics selected using the BIRCP method caused less physical side effects and were more cost effective.
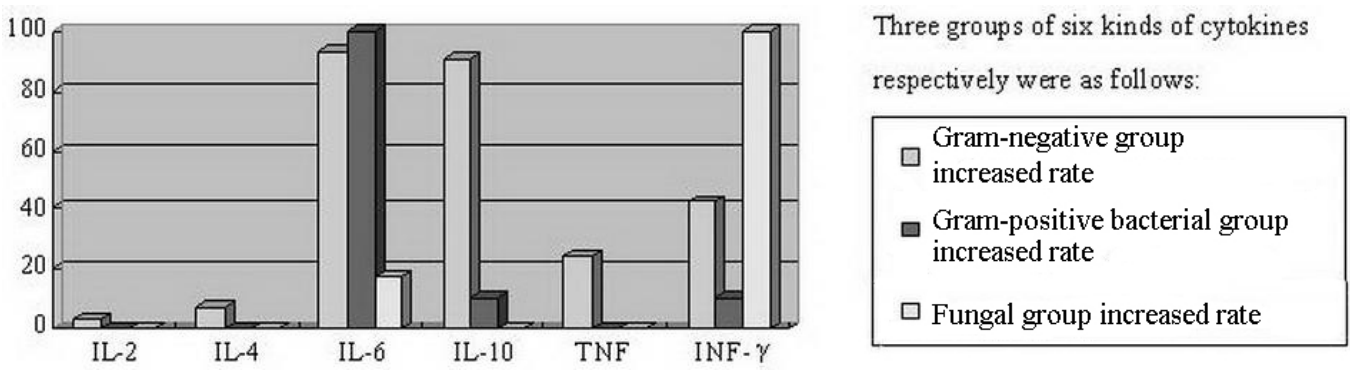

Figure 2. Blood culture-positive children.

Table 3. Comparison of efficacies in clinical treatment groups.
\begin{tabular}{lccrr}
\hline Groups & Effective number & Non-effective number & Total & Effective rate \\
\hline Based on BIRCP (1)* & 37 & 6 & 43 & $86.05 \%$ \\
Based on clinical experience $(2)^{* *}$ & 36 & 19 & 55 & $65.45 \%$ \\
Broad-spectrum cover (3)*** & 291 & 35 & 326 & $89.26 \%$ \\
Total & 364 & 60 & 424 & $85.84 \%$ \\
\hline
\end{tabular}

$\mathrm{BIRCP}=$ bacterial infection-related cytokine profile. $* \mathrm{VS} * * \mathrm{P}<0.05 ; * \mathrm{VS} * * * \mathrm{P}>0.05 ; * * \mathrm{VS} * * * \mathrm{P}<0.05$

\section{DISCUSSION}

Secondary nosocomial infection frequently occurs in children with hemopathy in the bone marrow inhibition phase. Infectious agents include bacteria, viruses, and fungi, among which Gram-negative bacteria are the most common (Wang et al., 2008; Bakhshi et al., 2008). When the specific pathogen or source cannot be identified, a broad-spectrum antibiotic is given, based on clinical experiences that have become the gold standard in the treatment of fever in pediatric tumor cases with granulocytopenia (Laws et al., 2005; Lehrnbecher and Laws, 2005). This method might lead to a higher treatment cost, waste of medical resources, 
and favor the development of antibiotic resistance (Simon et al., 2005). Therefore, methods to track the occurrence of infection symptoms in such patients are needed.

Many studies reported that cytokine profiles offer a sensitive index that can be measured early after bacterial infection and that plasma cytokine levels were well correlated to disease progression and prognosis (Tavares et al., 2005; Diepold et al., 2008; Ventetuolo and Levy, 2008) and could also be used to predict the mortality rate of septic shock (de Pablo et al., 2011). Previous studies reported that a single cytokine, such as IL-10, could predict Gram-negative versus Gram-positive bacterial infections, predicting Gram-negative bacterial sepsis (Spasova et al., 2005). In vitro studies also found a significant increase in IL-18 levels with Gram-positive bacterial infection (Feezor et al., 2003), but few studies have used Th1/Th2 cytokine profiles to predict infections by pathogens.

Statistical analysis of our data showed that certain cytokines increased within $24 \mathrm{~h}$ after infection in children with hemopathy in the bone marrow inhibition phase, which would normalize $24 \mathrm{~h}$ later, indicating that these cytokines faithfully indicated the status of the corresponding bacterial infection. The sensitivity of cytokine detection early after infection was greater than that of CRP levels or blood culture, and the cytokine profiles during infection gave a better indication of the infection control state than could CRP levels.

We found that $82.9 \%$ of Gram-negative bacterium-infected children showed IL-6 and IL-10 levels that were highly increased [ $>10$ times (means \pm SD)]; Gram-positive bacteriainfected children showed only a mild increase of IL-6 levels [ $>2$ times (means \pm SD)], and fungus-infected children showed only a mild increase of IFN- $\gamma$ levels [ $>2$ times (means \pm SD)], but not IL-6 or IL-10. Other studies, conducted in China and elsewhere, suggested that Grampositive bacterial and fungal infections could cause a mild increase in IL-6 levels (Lehrnbecher et al., 1999), whereas viral infection could cause an increase in IFN- $\gamma$ (Sutejo et al., 2012), but not in IL-6 or IL-10 levels (Engervall et al., 1995). Therefore, in this study, the high increases of IL-6 and IL-10 levels [ $>10$ times (means \pm SD)] in infected children could be considered to indicate Gram-negative bacterial infection. The treatment of children using Gram-positive and Gram-negative BIRCP forecasting of pathogen infections to guide the use of antibiotics was clearly more effective than drug selection based on clinical experience, and showed efficiency rates similar to multiple-coverage therapy with broad-spectrum antibiotics.

For children with hemopathy in the phase of bone marrow inhibition, fever is usually the only indication of infection, which is non-specific. The malignant disease and strong chemotherapy regimens impair immunity to infection in children with hemopathy. Once febrile children were given empirically chosen broad-spectrum antibiotics, the treatment cost and chances for drug resistance to emerge were reduced. Cytokines represent inflammatory markers that are produced soon after bacterial infections. They can reflect the nature of immunological suppression in children with fever, and thereby guide effective antibiotic selection and reduce the risk of death from nosocomial infection, as well as save costs and reduce the occurrence of bacterial resistance.

Nevertheless, although the use of BIRCP might robustly predict pathogen infection in children with hemopathy in the bone marrow inhibition phase, this method could not predict infections with $100 \%$ accuracy. Therefore, other potential concurrent pathogenic factors or polyinfection might have been occurring in some cases. For such cases, other modes of pathogenesis should be actively sought, and when necessary, the cytokine measurements should be repeated and the profiles used to adjust treatment regimens. 


\section{REFERENCES}

Bakhshi S, Padmanjali KS and Arya LS (2008). Infections in childhood acute lymphoblastic leukemia: an analysis of 222 febrile neutropenic episodes. Pediatr. Hematol. Oncol. 25: 385-392.

de Pablo R, Monserrat J, Reyes E and Diaz-Martin D (2011). Mortality in patients with septic shock correlates with antiinflammatory but not proinflammatory immunomodulatory molecules. J. Intensive Care Med. 26: 125-132.

Diepold M, Noellke P, Duffner U, Kontny U, et al. (2008). Performance of interleukin-6 and interleukin-8 serum levels in pediatric oncology patients with neutropenia and fever for the assessment of low-risk. BMC Infect. Dis. 8: 28.

Engervall P, Andersson B and Bjorkholm M (1995). Clinical significance of serum cytokine patterns during start of fever in patients with neutropenia. Br. J. Haematol. 91: 838-845.

Feezor RJ, Oberholzer C, Baker HV, Novick D, et al. (2003). Molecular characterization of the acute inflammatory response to infections with Gram-negative versus Gram-positive bacteria. Infect. Immun. 71: 5803-5813.

Ikonomidis I, Papadimitriou C, Vamvakou G, Katsichti P, et al. (2008). Treatment with granulocyte colony stimulating factor is associated with improvement in endothelial function. Growth Factors 26: 117-124.

Laws HJ, Ammann RA and Lehrnbecher T (2005). Diagnostic procedures and management of fever in pediatric cancer patients. Klin. Padiatr. 217 (Suppl 1): S9-16.

Lehrnbecher T and Laws HJ (2005). Infectious complications in pediatric cancer patients. Klin. Padiatr. 217 (Suppl 1): S3-S8.

Lehrnbecher T, Venzon D, de Haas M, Chanock SJ, et al. (1999). Assessment of measuring circulating levels of interleukin-6, interleukin-8, C-reactive protein, soluble Fc gamma receptor type III, and mannose-binding protein in febrile children with cancer and neutropenia. Clin. Infect. Dis. 29: 414-419.

Martins GA, Da Gloria Da Costa Carvalho and Rocha GC (2003). Sepsis: a follow-up of cytokine production in different phases of septic patients. Int. J. Mol. Med. 11: 585-591.

Mendes AV, Sapolnik R and Mendonca N (2007). New guidelines for the clinical management of febrile neutropenia and sepsis in pediatric oncology patients. J. Pediatr. 83: S54-S63.

Park KW, Kwon YW, Cho HJ, Shin JI, et al. (2008). G-CSF exerts dual effects on endothelial cells-opposing actions of direct eNOS induction versus indirect CRP elevation. J. Mol. Cell Cardiol. 45: 670-678.

Roitt I, Brostoff J and Male D (2001). Immunology. 6th edn. People's Medical Publishing House, Beijing.

Simon A, Beutel K, Marklein G and Fleischhack G (2005). Bacterial infections in pediatric cancer patients. Klin. Padiatr. 217 (Suppl 1): S17-S36.

Spasova MI, Terzieva DD, Tzvetkova TZ, Stoyanova AA, et al. (2005). Interleukin-6, interleukin-8, interleukin-10, and C-reactive protein in febrile neutropenia in children with malignant diseases. Folia Med. 47: 46-52.

Sutejo R, Yeo DS, Myaing MZ, Hui C, et al. (2012). Activation of type I and III interferon signalling pathways occurs in lung epithelial cells infected with low pathogenic avian influenza viruses. PLoS One 7: e33732.

Tárnok A, Hambsch J, Chen R and Varro R (2003). Cytometric bead array to measure six cytokines in twenty-five microliters of serum. Clin. Chem. 49: 1000-1002.

Tavares E, Maldonado R, Ojeda ML and Minano FJ (2005). Circulating inflammatory mediators during start of fever in differential diagnosis of gram-negative and gram-positive infections in leukopenic rats. Clin. Diagn. Lab. Immunol. 12: 1085-1093.

Ventetuolo CE and Levy MM (2008). Biomarkers: diagnosis and risk assessment in sepsis. Clin. Chest Med. 29: 591-603, vii.

von Lilienfeld-Toal M, Dietrich MP, Glasmacher A, Lehmann L, et al. (2004). Markers of bacteremia in febrile neutropenic patients with hematological malignancies: procalcitonin and IL-6 are more reliable than C-reactive protein. Eur. $J$. Clin. Microbiol. Infect. Dis. 23: 539-544.

Wang A, Fan S, Yang Y and Shen X (2008). Nosocomial infections among pediatric hematology patients: results of a retrospective incidence study at a pediatric hospital in China. J. Pediatr. Hematol. Oncol. 30: 674-678. 